\title{
GC-MS Analysis of Phytochemical Constituents from Ethyl Acetate and Methanol Extract of Artocarpus altilis (Parkinson) Fosberg from Endau Rompin, Johor, Malaysia
}

\author{
Muhammad Murtala Mainasara ${ }^{1,2}$, Mohd Fadzelly Abu Bakar ${ }^{1}$, Aisha Ibrahim Barau ${ }^{3}$ \\ ${ }^{1}$ Universiti Tun Hussein Onn Malaysia \\ 101 Parit Raja, Batu Pahat, Johor, 86400, Malaysia \\ ${ }^{2}$ Usmanu Danfodiyo University \\ P. M. B. 2346, Sokoto, Nigeria \\ ${ }^{3}$ Kaduna State University \\ P. M. B 2339, Kaduna State, Nigeria
}

DOI: $10.22178 /$ pos. $46-2$

LCC Subject Category: QH301-705.5

Received 20.04.2019

Accepted 27.05.2019

Published online 31.05.2019

Corresponding Author:

Muhammad Murtala

mmgusau96@gmail.com

(c) 2019 The Authors. This article

is licensed under a Creative Commons

Attribution 4.0 License @)

\begin{abstract}
. Шn the present days, medicinal plants receive great attention to the researchers in the field of pharmacology, due to the fact that most of the drug industries rely on natural products more especially medicinal plants for the production of new drugs. Some traditional medicines and their derived products were often made from crude plant extracts, which include a mixture of complex different phytochemical constituents. The chemical features of these constituents vary substantially among different species. Gas chromatography and Mass spectroscopy (GC-MS) method used for the analysis of the obtained extracts can be a remarkable tool for screening the quantity of some active principles in herbs used in pharmaceutical industries. The identification of secondary metabolites is based on the peak area, retention time molecular weight, molecular formula, MS Fragment- ions and Pharmacological actions. The aim of this study was to carry out for identification of bioactive compounds from the leaf ethyl acetate and methanolic extract of Artocarpus altilis by (GC-MS). Fifty and fifteen bioactive phytochemical compounds were identified in the methanolic and ethyl acetate extracts respectively. GC/MS analysis revealed the existence of Acetic acid, n-Hexadecanoic acid, 1,2,3-Propanetriol, 1-acetate (Acetin), Hexadecanoate <methyl->, 7-Tetradecenal, in the methanol extract while the ethyl acetate extract revealed the presence of 3, 7-dimethyl-2, 6octadienal (Geranial-pseudo phytol), 3,7,11,15Tetramethyl-2-hexadecen-1-ol (Phytol), Piperonal and Heliotropin. Further studies are needed to isolate active principle of the extract as well as to elucidate their exact mechanism of action in various disorders.
\end{abstract}

Keywords: Artocarpus altilis; GC-MS; medicinal plants; pharmacology; phytochemical compounds.

\section{INTRODUCTION}

The genus Artocarpus belongs to the family Moraceae which comprises about 60 genera and over 1000 species. Many of these species are used as a source of food and in traditional medicinal practices [14]. Artocarpus species are known for its large edible fruit with high nutritive values. The important species belonging to this genus are $A$. heterophyllus, $A$. altilis, A. hirsutus, A. lakoocha and A. camansi. Other than fruits and seeds, extracts of aerial and underground parts have been used traditionally in the treatment of diabetes, diarrhoea, dermatitis, malarial fever, asthma, tapeworm infection, anaemia and many other diseases [14]. Also the plant latex has significant contribution in medicine as it contains biologically active compounds such as alkaloids, flavonoids, terpenoids, glycosides, phenolics, tannins and saponins etc. which are not only beneficial for plant defence but also for the development of things such as disinfectants, anticoagulant [8]. Islanders use the latex of $A$. altilis to 
treat skin diseases, stomach ache, diarrhoea and dysentery [30]. Crushed leaves are used to treat skin, ear and eye infections. Other medicinal uses include the roots as stringent, purgative and poultice for skin ailments, and the bark for treating headache.

The fruit is an excellent source of fibre, calcium, copper, iron, magnesium, potassium, thiamine, niacin, carbohydrates, and vitamin [1]. These plants are known to contain many potential bioactive phytochemicals which possess many validated pharmacological properties [13]. Artocarpus species are mainly distributed in tropical and subtropical regions of Asia A. altilis (breadfruit) is native to New Guinea, Indonesia and Philippines. Currently, they are cultivated in central and South America, Africa, India, Southeast Asia, Maldives, Indonesia, Srilanka and northern Australia. A. altilis (Parkinson) Fosberg (breadfruit). Synonyms of $A$. altilis are $A$. communis and $A$. incisus). The generic name of the species comes from the Greek words 'artos' (bread), and 'karpos' (fruit) and the fruits eaten are commonly called breadfruit [34]. In general, breadfruit trees are very large, an evergreen which can reach heights of 15 to 20 meters. The tree comprises smooth, lightcoloured bark, and the trunk is large in $1.2 \mathrm{~m}$ in diameter, occasionally growing to a height of $4 \mathrm{~m}$ before branching. The wood is gold in colour, but when contact with air, turns to a darker colour. Latex can be seen in all parts of the tree which are milky [34].

Breadfruits are available with seeds and also without seeds, the seeded types of breadfruit are available in south-western Pacific, whereas seedless types of breadfruit are common in Micronesia and Eastern islands of Polynesia. All the breadfruit varieties elsewhere, especially in the topic region, are of a seedless type. Seeds are brown in colour, shiny, round or ovoid and irregularly compressed. Moreover, the seeds have little or no endosperm, no period of dormancy and they can germinate immediately. Since they can germinate immediately, they are not able to be dried or stored. Trees that grow with the help of seeds can produce their fruits in a timeline of 6-10 years or sooner. On the contrary, asexually propagated trees can start to produce their fruits in about three to six years of time.

Fruits of breadfruit are nutritious and are consumed as a starchy staple when mature. They are rich in carbohydrates and contain vitamins and minerals. A fruit quality evaluation of 20 bread- fruit cultivars sampled from the National Tropical Botanical Garden in Hawaii showed significant differences in aroma, texture, colour, flavour, sweetness, starchiness, moistness, stringiness and firmness [30]. The most significant differences were in colour and texture. Nutrient analyses showed that the pulp of mature fruits of A. altilis (100 g) contained $69 \%$ of water, $1.0 \mathrm{~g}$ of protein, $29 \mathrm{~g}$ of carbohydrate, $5.2 \mathrm{~g}$ of dietary fibre, $22 \mathrm{mg}$ of sodium, $24 \mathrm{mg}$ of magnesium, 32 mg of phosphorous, $350 \mathrm{mg}$ of potassium and 20 mg of calcium on the average. The content of vitamin $\mathrm{C}, \beta$-carotene and lutein was $3.8 \mathrm{mg}, 13 \mu \mathrm{g}$ and $72 \mu \mathrm{g}$, respectively. Breadfruit is a good source of vitamin $C$, thiamine, riboflavin and niacin. Nutritionally, breadfruit is comparable or superior to other staple food commonly consumed in Oceania, e.g., taro, plantain, cassava, sweet potato and rice.

Artocarpus genus can produce a large number of secondary metabolites usually abundant in phenylpropanoids such as flavonoids and flavones. They also produce phenolic compounds including flavonoids, stilbenoids and arylbenzofurons. Over 130 compounds are identified in various organs of $A$. altilis, more than 70 of which derived from the phenylpropanoid pathway [34]. Many of the isolated compounds exhibit biological activity such as inhibit platelet aggregation, anti-bacterial activity, anti-fungal properties, inhibition of leukaemia cells and as an anti-tumour agent [6]. Some of the bioactive compounds that were isolated and found to be responsible for the anticancer activities from $A$. altilis that exhibited good activity are pyranocycloartobiloxanthone $\mathrm{A}$ (PA), dihydro-artoindonesianin $\mathrm{C}$, and pyranocycloartobiloxanthone B isolated from A. obtusus [27]. Nutritional compositions of the seeds have water, protein, carbohydrate, fat, calcium, phosphorus, iron, niacin, thiamine and vitamin $\mathrm{C}$ [9]. $A$. altilis contains some chemical constituents such as morin, moracin, dihydromorin, cynomacurin, Early chemical analysis of fruits of $A$. altilis led to the isolation of triterpenes of cycloartenol, cycloart-23-ene- 3 3,25 -diol, cycloart-25-ene-3 $\beta, 24$-diol and $\alpha$-amyrin volatile chemicals of fresh and cooked fruits of $A$. altilis have been studied. In fresh breadfruit, 40 volatile compounds were identified with cis-3hexanol (36\%) being the major constituent. Out of 43 volatile compounds identified in breadfruit boiled for $10 \mathrm{~min}$, the main component was ethyl acetate (38\%). From the methanol and ethyl acetate fruit extracts of $A$. altilis, arylbenzofuran of 
moracin M; stilbenes of oxyresveratrol and artoindonesianin F; flavonoids of norartocarpanone, Artocapin, norartocarpetin and isoartocarpesin; triterpenes of 3ßacetoxyolean-12-en11-one and cycloartenol acetate; and sterols of sitosterol $\beta$-Dglucopyranoside and sitosterol have been isolated [22]. A. altilis have been reported to possess antioxidant and antimicrobial activities, a comparative study has been conducted on the antioxidant properties of the pulp, peel and whole fruit of $A$. altilis extracted with hexane, dichloromethane and methanol [22].

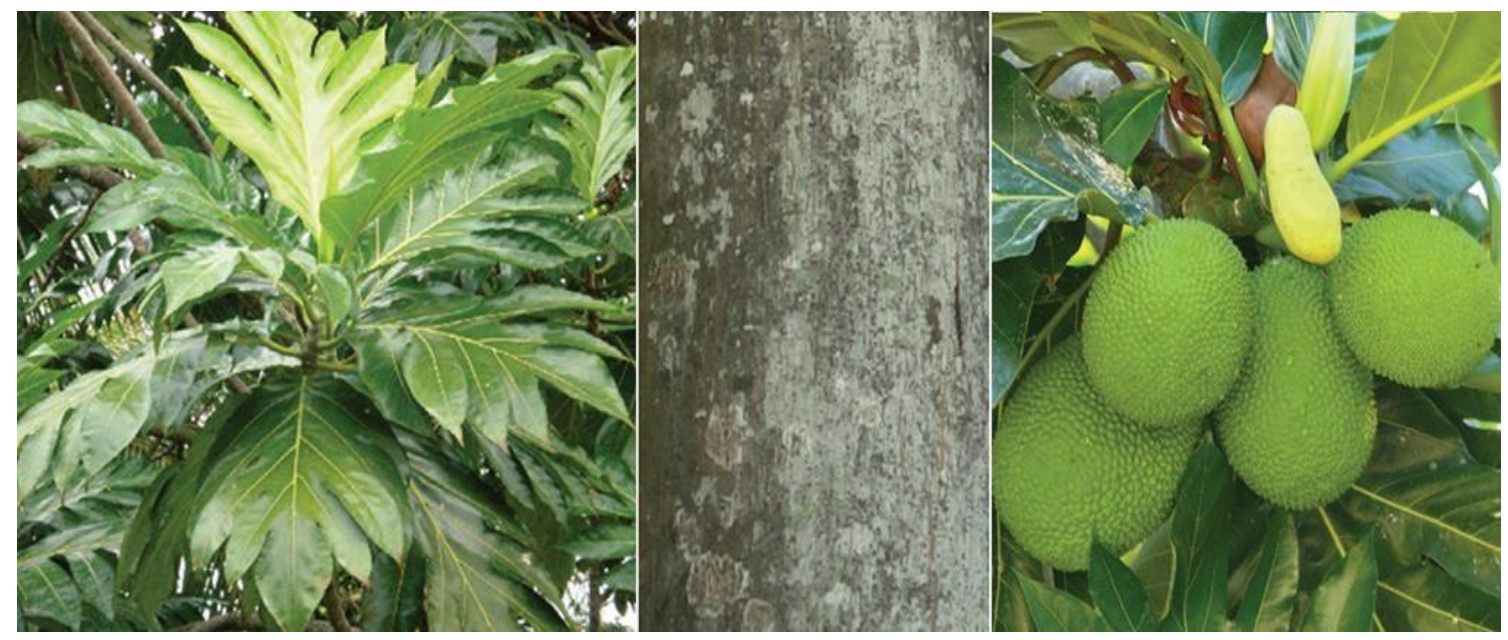

Figure 1 - Leaves, Stem and Fruits of A. Altilis

\section{MATERIALS AND METHODS}

The study was conducted in the rainforest of Kampung Peta located border to the north-east of Endau, Johor Darul Takzim and south to Rompin, Pahang. The forest $\left(2^{\circ} 25^{\prime} 12.94 " \mathrm{~N}\right.$, $\left.103^{\circ} 15^{\prime} 40.94^{\prime \prime} \mathrm{E}\right)$ is among the few lasting virgin lowland rainforest areas in the southern part of Peninsular Malaysia. The state government of Johor in 1993 gazette $870 \mathrm{~km}^{2}$ or 48,905 hectares of the Taman Negara Johor Endau Rompin (TNJER) forest as a national park [21].

The fresh sample (leaves) were collected under a permit granted by Perbadanan Taman Negara Johor (PTNJ) following the WHO guidelines on Good Agricultural and Collection Practices for Medicinal Plants. The samples as wild types from various locations earlier mentioned in May 2017. Roughly 1 to $4 \mathrm{~kg}$ of the fresh samples were collected and placed into a labelled plastic bags.

Plant materials were carefully clean and rinse by using distilled water to remove contaminant or soil debris. The samples were dried in the shade at room temperature and ground in a mortar or dried in the oven for two days at $40^{\circ} \mathrm{C}$. The dried sample will grinded to a fine powder using a dry grinder or pestle and mortar, the ground sample was kept in ziplock bag and to be stored in a freezer $\left(-20^{\circ} \mathrm{C}\right)$ for further analysis $[20,32]$.
The extraction of plant samples using organic solvents was carried out by successive maceration extraction as previously described by [7] with few modifications. Organic solvents with different polarities such as nhexane (non-polar), ethyl acetate (intermediate polar) and methanol (highly polar) were used. All the organic solvents used were obtained from Merck, Germany. One hundred grams of powdered plant materials were sequentially macerated with the specified volume of ethyl acetate and methanol in the order of increasing polarity of the solvents in 1:5 ratios in an enclosed flask with occasional shaking. The extraction was repeated three times until complete extraction. The mixture was kept at room temperature for $24 \mathrm{~h}$. At each stage of extraction, the sample debris produced after filtration was left in a sterile fume hood to dry before being used in the subsequent extraction stage. The solvent from each sample was then filtered through a vacuum filter and then evaporated to a minimum volume under reduced pressure in a rotary evaporator set at $40^{\circ} \mathrm{C}$ in a water bath. The resultant dried crude extracts from each plant were packed in glass bottles with accurate labels, and the yield of extracts was calculated using the formula below. Then the extracts were stored at $4{ }^{\circ} \mathrm{C}$ in a refrigerator until use.

The extraction yield was determined to be used as an indicator of the effects of the extraction 
condition and expressed as percentage using the formula below (1).

$$
\begin{aligned}
& \text { Percentage yield }= \\
& =\frac{\text { Mass of recovered crude extract }}{\text { Mass of starting plant material }} \times 100
\end{aligned}
$$

The gas chromatography-mass spectroscopy (GC-MS) analysis was conducted on methanol extract of A. altilis (AAM) and ethyl acetate extract (AAE). The peaks (Figure 2) in the chroma- togram were integrated and compared with the database of spectra of known compounds stored in the GC-MS libraries of National Institute Standard and Technology, WILEY229.LIB, PflegerMaurer-Weber-Drugs-and-. $\quad$ PesticidesLibrary for toxicology (PMW_tox2) and Flavour, Fragrance, Natural and Synthetic Compounds (FFNSC1.3.lib). The detailed tabulation of GC-MS analysis of the selected active extracts was given below in Table 1 and 2 .

\begin{tabular}{|c|c|c|c|c|}
\hline $\begin{array}{c}\text { Peak } \\
\text { No }\end{array}$ & $\begin{array}{c}\mathrm{RT} \\
(\mathrm{min})\end{array}$ & Name of identified compounds & $\begin{array}{c}\text { Area } \\
(\%)\end{array}$ & $\mathrm{S} / \mathrm{I}$ \\
\hline 1 & 2.617 & Acetic acid & 34.68 & 98 \\
\hline 29 & 50.958 & n-Hexadecanoic acid & 14.89 & 92 \\
\hline 9 & 15.116 & 1,2,3-Propanetriol, 1-acetate (Acetin) & 7.28 & 95 \\
\hline 28 & 49.678 & Hexadecanoate $<$ methyl-> & 4.01 & 94 \\
\hline 11 & 22.122 & Glycerol .alpha.-monoacetate & 2.80 & 95 \\
\hline 36 & 56.595 & 7-Tetradecenal, (Z)- & 2.92 & 86 \\
\hline 33 & 55.808 & Phytol & 2.46 & 93 \\
\hline 37 & 57.302 & Octadecanoic acid & 2.26 & 91 \\
\hline 50 & 86.925 & Cholesterol & 2.10 & 73 \\
\hline 30 & 51.969 & Palmitic acid & 1.35 & 78 \\
\hline 32 & 55.412 & Linolenate $<$ methyl- $>$ & 1.32 & 86 \\
\hline 27 & 49.081 & 8-Oxabicyclo[5.1.0]oct-5-en-2-ol, 1,4,4-trimethyl & 1.28 & 78 \\
\hline 18 & 38.767 & Megastigmatrienone & 1.28 & 87 \\
\hline 8 & 12.341 & 1,2,3-Propanetriol & 1.23 & 84 \\
\hline 19 & 40.163 & 4,4,5,8-Tetramethylchroman-2-ol & 1.22 & 72 \\
\hline 12 & 22.328 & Guaiacol <4-vinyl-> & 1.20 & 88 \\
\hline 35 & 56.404 & cis-9,cis-12-Octadecadienoic acid & 1.18 & 89 \\
\hline 2 & 2.773 & 2-Propanone, 1-hydroxy- Acetol & 1.08 & 97 \\
\hline 25 & 46.659 & Neophytadiene & 1.06 & 93 \\
\hline 23 & 44.975 & Methylhydroquinone, & 1.04 & 84 \\
\hline 10 & 17.313 & 2,3-dihydro-3,5-dihydroxy-6-methyl-4h-pyran-4-one & 0.99 & 90 \\
\hline 15 & 34.157 & (Phenol) 2,4-bis(1,1-dimethylethyl)- (CAS) 2,4-Di-tert-butylphenol & 0.94 & 83 \\
\hline 43 & 67.225 & 2-hydroxy-1-(hydroxymethyl)ethyl ester & 0.84 & 85 \\
\hline 31 & 55.215 & 9,12-Octadecadienoic acid (Z,Z)-, methyl ester (Linoleic acid) & 0.82 & 91 \\
\hline 34 & 56.226 & Methyl stearate & 0.76 & 91 \\
\hline 47 & 82.437 & Vitamin E & 0.61 & 88 \\
\hline 4 & 3.735 & :2-Propyn-1-ol & 0.57 & 92 \\
\hline 6 & 7.761 & 3(5)-d1-1,2,4-triazole & 0.55 & 85 \\
\hline 20 & 43.046 & Coniferyl alcohol & 0.53 & 81 \\
\hline 41 & 62.105 & Methyl 12-hydroxyoctadecanoate & 0.51 & 79 \\
\hline 17 & 38.294 & Megastigmatrienone & 0.51 & 80 \\
\hline 21 & 44.115 & $\begin{array}{l}\text { 2(4H)-Benzofuranone, 5,6,7,7a-tetrahydro-6-hydroxy-4,4,7a-trimethyl-, (6S- } \\
\text { cis)- (CAS) Loliolide }\end{array}$ & 0.48 & 87 \\
\hline 40 & 60.943 & Octanoic acid & 0.36 & 89 \\
\hline 13 & 25.371 & Triacetin & 0.35 & 73 \\
\hline 49 & 86.605 & 16-Hentriacontanone & 0.35 & 76 \\
\hline 39 & 60.231 & 14-.beta.-h-pregna & 0.34 & 83 \\
\hline 7 & 7.955 & 2-Hydroxy-2-cyclopenten-1-one & 0.32 & 86 \\
\hline 24 & 45.945 & Cyclopentanecarboxylic acid & 0.32 & 77 \\
\hline
\end{tabular}

Table 1 - Phytochemical compounds identified in methanol extract of $A$. altilis 


\begin{tabular}{|c|c|l|c|c|}
\hline $\begin{array}{c}\text { Peak } \\
\text { No }\end{array}$ & $\begin{array}{c}\text { RT } \\
(\mathrm{min})\end{array}$ & \multicolumn{1}{|c|}{ Name of identified compounds } & $\begin{array}{c}\text { Area } \\
(\%)\end{array}$ & \begin{tabular}{c} 
S/I \\
\hline 22
\end{tabular} \\
44.551 & 4-(3-Hydroxy-2,2,6-trimethyl-7-oxa-bicyclo[4.1-0]hept-1-yl)-but-3-en-2-one & 0.30 & 73 \\
\hline 16 & 36.894 & 4-[(1E)-1,3-Butadienyl]-3,5,5-trimethyl-2-cyclohexen-1-one & 0.28 & 80 \\
\hline 5 & 3.983 & Methyl acetate & 0.26 & 84 \\
\hline 26 & 48.163 & 2,6,10-trimethyl,14-ethylene-14-pentadecne & 0.25 & 88 \\
\hline 3 & 3.430 & Glycerin & 0.21 & 87 \\
\hline 14 & 27.066 & 2,4-bis(1,1-dimethylethyl)- (CAS) 2,4-Di-tert-butylphenol & 0.21 & 93 \\
\hline 42 & 63.008 & 2H-Pyran-2-one, tetrahydro-6-tridecyl- & 0.21 & 77 \\
\hline & & Total compounds & $\mathbf{4 5}$ & \\
\hline & & Total Identified & $\mathbf{9 8 . 4 9}$ & \\
\hline
\end{tabular}

Table 2 - Phytochemical compounds identified in the Ethyl acetate crude extract of $A$. altilis using GC-MS analysis

\begin{tabular}{|c|c|l|c|c|}
\hline Peak No & $\begin{array}{c}\text { RT } \\
(\mathrm{min})\end{array}$ & \multicolumn{1}{|c|}{ Name of identified compounds } & $\begin{array}{c}\text { Area } \\
(\%)\end{array}$ & S/I \\
\hline 11 & 59.717 & 3, 7-dimethyl-2, 6-octadienal (Geranial-pseudo phytol) & 59.95 & 99 \\
\hline 5 & 49.566 & 3,7,11,15-Tetramethyl-2-hexadecen-1-ol (Phytol) & 8.80 & 93 \\
\hline 8 & 53.646 & Piperonal, (Heliotropin) & 7.22 & 88 \\
\hline 12 & 65.428 & $\begin{array}{l}\text { 3,7,11,15-Tetramethyl-1,6,10,14-hexadecatetraen-3-ol; (6E,10E)- } \\
\text { geranyllinalool }\end{array}$ & 4.41 & 96 \\
\hline 7 & 50.991 & Phytol acetate & 3.13 & 96 \\
\hline 3 & 25.987 & Stearic acid; n-Octadecanoic acid & 3.06 & 92 \\
\hline 14 & 65.525 & Neral (Pseudo-phyto<6Z,10Z) & 2.28 & 89 \\
\hline 6 & 50.408 & Citronellyl pentanoate & 2.02 & 97 \\
\hline 13 & 65.462 & Farnesyl acetate (Farnesol) & 1.92 & 98 \\
\hline 9 & 54.665 & Palmitic acid (Hhexadecanoic acid) & 1.65 & 94 \\
\hline 2 & 18.662 & 1,2,4,5-Tetramethylbenze (Durol) & 1.53 & 89 \\
\hline 10 & 59.162 & 7,11-Dimethyldodeca-2,6,10-trien-1-ol & 1.35 & 97 \\
\hline 4 & 26.238 & 1,2,3-triacetoxypropane (Triacetin) & 1.08 & 83 \\
\hline 1 & 4.197 & 4-hydroxy-4-methyl-2-pentanone & 0.92 & 95 \\
\hline 15 & 67.139 & Presilphiperfolan-8-ol & 0.68 & 91 \\
\hline & & Total compounds & $\mathbf{1 5}$ & \\
\hline & & Total Identified & $\mathbf{1 0 0}$ & \\
\hline
\end{tabular}

\section{RESULTS AND DISCUSSION}

The quantity of recovered crude extracts varied according to the solvent used. It has been shown that methanol yielded relatively higher amounts of crude extracts. A. altilis (leaves) extracted with methanol yielded the highest crude extract $14.20 \%$, while ethyl acetate had $5.83 \%$, from approximately 2-3 $\mathrm{kg}$ of shade dried powdered leaves. Most of the constituents were polar in nature.

The result of AAM revealed 50 peaks (Figure 2 (A), with 45 compounds identified (Table 1) representing $98.49 \%$ of the entire extract. The major among them were Acetic acid (34.68\%), nHexadecanoic acid (14.89\%), 1,2,3-Propanetriol, 1-acetate (Acetin) (7.28\%), Hexadecanoate $<$ methyl-> (4.01\%), 7-Tetradecenal, (Z)- (2.92\%) Glycerol alpha.-monoacetate (2.80\%), Phytol (2.46\%), Octadecanoic acid (2.26\%), Cholesterol
(2.10\%), Palmitic acid (1.35\%), , Linolenate $<$ methyl-> (1.32\%), Megastigmatrienone and 8Oxabicyclo[5.1.0]oct-5-en-2-ol, 1,4,4-trimethyl (1.28\%) each, 1,2,3-Propanetriol (1.23\%) and 4,4,5,8-Tetramethylchroman-2-ol (1.22\%).

The result of AAE revealed 15 peaks (Figure 2(B), with 15 compounds identified (Table 2) representing $100 \%$ of the entire extract. The major among them were 3, 7-dimethyl-2, 6-octadienal (Geranial-pseudo phytol) (59.95\%), 3,7,11,15Tetramethyl-2-hexadecen-1-ol (Phytol) (8.80\%), Piperonal, (Heliotropin) (7.22\%), 3,7,11,15Tetramethyl-1,6,10,14-hexadecatetraen-3-ol; (6E,10E)-geranyllinalool (4.417 Phytol acetate (3.13\%), Stearic acid; n-Octadecanoic acid (3.06\%), Neral (Pseudo-phyto<6Z,10Z) (2.28\%), Citronellyl pentanoate (2.02\%), Farnesyl acetate (Farnesol) (1.92\%), Palmitic acid (Hhexadecanoic acid) (1.65\%) 1,2,4,5Tetramethylbenze (Durol) (1.53\%), 7,11- 
Dimethyldodeca-2,6,10-trien-1-ol (1.35\%) and 1,2,3-triacetoxypropane (Triacetin) (1.08\%).

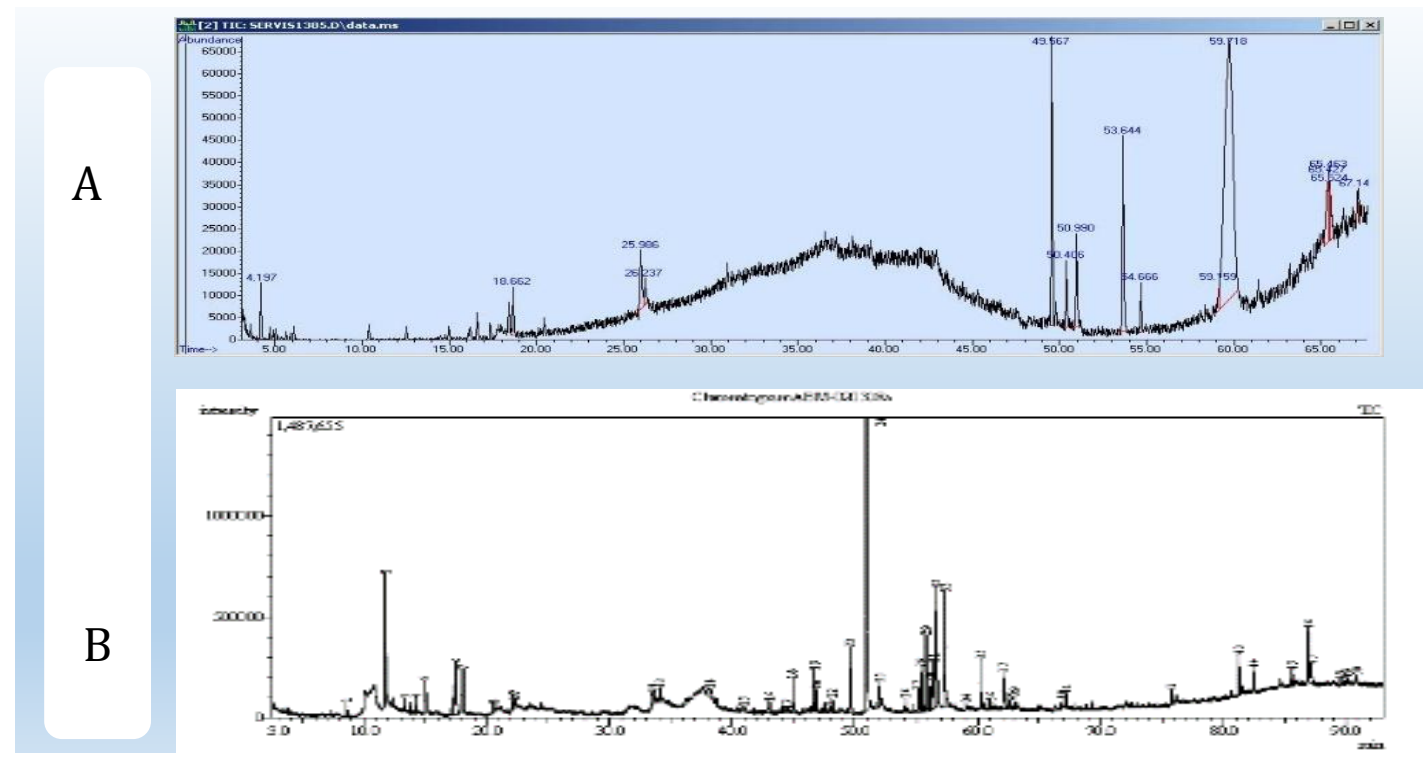

Figure 2 - GC chromatograms of (A) AAM (B) AAE

Tropical rainforests contain a lot of interesting pharmacologically active constituents, and many more are still waiting to be discovered as they still offer undoubtedly valuable and amazing chemical entities [15]. Natural products are the chemical compounds found in nature that usually has a pharmacological or biological activity for use in pharmaceutical drug discovery and drug design. The chemical constituents in the plants or crude extracts are known to be biologically active ingredients. Some chemical constituents are considered as secondary metabolites components. They are directly responsible for different activity such as antioxidant, antimicrobial, antifungal and anticancer [16]. Many anticancer drugs have been showing a clinical success were elaborated from naturally occurring molecules or developed from their synthetic analogues. Great interest is currently being paid to natural products because of their interesting anticancer activity [31]. Drugs of natural origin have been classified as original natural products; products derived semisynthetically from natural products or synthetic products based on natural product models [10].

Collectively, plants produce a remarkably diverse array of over 100,000 low molecular-mass natural products, al o known as secondary metabolites. Secondary metabolites are distinct from the components of intermediary (primary) metabolism in that they are generally nonessential for the basic metabolic processes of the plant. Many secondary metabolites have been isolated and characterised from a variety of natural sources, such as bacteria, fungi, and plants. They are of high interest and importance because they often exhibit a broad spectrum of biological activities. Phytochemicals are nonnutritive chemicals and responsible for the medicinal properties of plants $[28,38]$. Different crude extracts were obtained from the leaves of $A$. altilis through successive maceration with solvents of increasing polarity, viz., ethyl acetate and methanol. GC-MS analysis of ethyl acetate and methanol extracts revealed the presence of various bioactive compounds.

Phytol is present both in methanol (2.46\%) and ethyl acetate extracts (8.80\%) but in different quantities. This compound is a diterpene, a member of the group of branched chain unsaturated fatty alcohols. It is the product of chlorophyll metabolism in plants that is abundantly present [11]. The literature revealed phytol have vast biological activities including antiinflammatory, antimicrobial, cytotoxic, neuroprotective, antidiabetic and antioxidant [19]. Some previous studies proved that phytol exhibited cancer preventive and antioxidant [35, 36, 37] and breast cancer specifically $[12,18,33]$.

Hexadecanoic acid was also identified in both methanol (4.01\%) and ethyl acetate (1.65\%) extracts. The compound is the most common longchain saturated fatty acid that is naturally produced by the wide range of plants, animals, and microorganisms. The compound was found in the literature to possess vast bioactivity such as antibacterial, anti-inflammatory, anti-fungal [2, 17], antioxidant [23], pesticide, antioxidant, hypocholesterolemic nematicide and 5-Alphareductase inhibitor $[17,24]$. Furthermore, hexa- 
decanoic acid was recently reported to poses cytotoxic activities against cancer cell lines $[5,17$, 26]. Thus, the effective anti-proliferative activities demonstrated by the selected crude extracts in this study might be contributed by the synergistic effect of this compound with the other compounds identified. Palmic acid and triacetin was present both in methanol $(1.35 \%)$ and $(0.35)$ and, ethyl acetate extracts $(1.65 \%)$ and (1.08) respectively. These biological activities of compounds present in A. altilis leaf extract support the medicinal application of the plant. The study revealed major bioactive compounds present in all of the extracts. Identification of these compounds in the plant serves as the basis in determining the possible health benefits of the plant leading to further biologic and pharmacologic studies.

In addition, naturally occurring vitamin $\mathrm{E}$ found naturally in some foods was also found in methanol extract. Vitamin $\mathrm{E}$ exists in eight chemical forms (alpha-, beta-, gamma-, and deltatocopherol and alpha-, beta-, gamma-, and deltatocotrienol) that have varying levels of biological activity [25]. Vitamin E is a fat-soluble antioxidant that stops the production of ROS formed when fat undergoes oxidation. Despite its activi- ties as an antioxidant, vitamin $\mathrm{E}$ is involved in immune function and, as shown primarily by in vitro studies of cells, cell signalling, regulation of gene expression, and other metabolic processes $[29,40]$, it was reported that vitamin C-induced cell death as observed in many cancer cells [39].

\section{CONCLUSIONS}

The two extracts possess major bioactive compounds that were identified and characterized spectroscopically. Thus, identification of different biologically active compounds in the extracts of $A$. altilis leaves warrants further biological and pharmacological studies.

\section{ACKNOWLEDGMENTS}

This study was supported by Universiti Tun Hussein Onn Malaysia under GPPS grant (No 608) by Office for Research, Innovation, Commercialization and Consultancy.

\section{CONFLICT OF INTEREST STATEMENT}

We declare that we have no conflict of interest.

\section{REFERENCES}

1. Akanni, O. O., Owumi, S. E., \& Adaramoye, O. A. (2014). In vitro studies to assess the antioxidative, radical scavenging and arginase inhibitory potentials of extracts from Artocarpus altilis, Ficus exasperate and Kigelia africana. Asian Pacific Journal of Tropical Biomedicine, 4, S492-S499. doi: 10.12980/apjtb.4.2014c581

2. Aparna, V., Dileep, K. V., Mandal, P. K., Karthe, P., Sadasivan, C., \& Haridas, M. (2012). AntiInflammatory Property of n-Hexadecanoic Acid: Structural Evidence and Kinetic Assessment. Chemical Biology \& Drug Design, 80(3), 434-439. doi: 10.1111/j.1747-0285.2012.01418.x

3. Arung, E. T., Muladi, S., Sukaton, E., Shimizu, K. \& Kondo, R. (2018). Artocarpin, a promising compound as whitening agent and anti-skin cancer. Jurnal Ilmu dan Teknologi Kayu Tropis, 6(1), 33-36.

4. Balasubramanian, J., Dhanalakshmi, R., Jibnomen, P. \& Manimekalai, P. (2012). A preclinical evaluation on antioxidant and gastroprotective effect of Dioscorea bulbifera in Wistar rats. Indian Journal of Innovations and Developments, 1(3), 149-154.

5. Beeharry, N., Lowe, J. E., Hernandez, A. R., Chambers, J. A., Fucassi, F., Cragg, P. J., ... Green, I. C. (2003). Linoleic acid and antioxidants protect against DNA damage and apoptosis induced by palmitic acid. Mutation Research/Fundamental and Molecular Mechanisms of Mutagenesis, 530(1-2), 2733. doi: 10.1016/s0027-5107(03)00134-9

6. Bhandari, M. R., Jong-Anurakkun, N., Hong, G., \& Kawabata, J. (2008). $\alpha$-Glucosidase and $\alpha$-amylase inhibitory activities of Nepalese medicinal herb Pakhanbhed (Bergenia ciliata, Haw.). Food Chemistry, 106(1), 247-252. doi: 10.1016/j.foodchem.2007.05.077 
7. Bhunu, B., Mautsa, R., \& Mukanganyama, S. (2017). Inhibition of biofilm formation in Mycobacterium smegmatis by Parinari curatellifolia leaf extracts. BMC Complementary and Alternative Medicine, 17(1). doi: 10.1186/s12906-017-1801-5

8. Chavan Bhagyashri, A., Hundiwale Jogendra, C. \& Patil Avinash, V. (2015). Plant latex: an inherent spring of pharmaceuticals. World Journal of Pharmacy and Pharmaceutical Science, 4(4), 17811796.

9. Chuku, E. \& Wekhe, O. (2017). Effects of Fungi Flora of Artocarpus Altilis on the Nutrient Components. International Journal of Agriculture and Earth Science, 3(8), 60-67.

10. Cragg, G. M., \& Newman, D. J. (2013). Natural products: A continuing source of novel drug leads. Biochimica et Biophysica Acta (BBA) - General Subjects, 1830(6), 3670-3695. doi: 10.1016/j.bbagen.2013.02.008

11. Cseke, L. J., Kirakosyan, A., Kaufman, P. B., Warber, S., Duke, J. A. \& Brielmann, H. L. (2006). Natural products from plants (2nd ed.). Boca Raton: CRC press.

12. Enriquez-Navas, P. M., Wojtkowiak, J. W., \& Gatenby, R. A. (2015). Application of Evolutionary Principles to Cancer Therapy. Cancer Research, 75(22), 4675-4680. doi: 10.1158/00085472.can-15-1337

13. Foo, J. B., Yazan, L. S., Tor, Y. S., Armania, N., Ismail, N., Imam, M. U., ... Ismail, M. (2014). Induction of cell cycle arrest and apoptosis in caspase-3 deficient MCF-7 cells by Dillenia suffruticosa root extract via multiple signalling pathways. BMC Complementary and Alternative Medicine, 14(1). doi: 10.1186/1472-6882-14-197

14. Hari, A., Revikumar, K. G., \& Divya, D. (2014). Artocarpus: A review of its phytochemistry and pharmacology. Journal of Pharma Search, 9(1), 7-12.

15. Hashim, N. M., Rahmani, M., Ee, G. C. L., Sukari, M. A., Yahayu, M., Amin, M. A. M., ... Go, R. (2012). Antioxidant, Antimicrobial and Tyrosinase Inhibitory Activities of Xanthones Isolated from Artocarpus obtusus F.M. Jarrett. Molecules, 17(5), 6071-6082. doi: 10.3390/molecules17056071

16. Hossain, N., Mirghani, M. E. S., \& Raus, R. B. (2015). Optimization of Moringa oleifera Leaf Extraction and Investigation of Anti Breast Cancer Activity with the Leaf Extract. Engineering International, 3(2), 97. doi: 10.18034/ei.v3i2.775

17. Imad, H. H., Hussein, J. H., Muhanned, A. K., \& Nidaa, S. H. (2015). Identification of five newly described bioactive chemical compounds in methanolic extract of Mentha viridis by using gas chromatography - mass spectrometry (GC-MS). Journal of Pharmacognosy and Phytotherapy, 7(7), 107-125. doi: 10.5897/jpp2015.0349

18. Islam, M. T., de Alencar, M. V. O. B., da Conceição Machado, K., da Conceição Machado, K., de Carvalho Melo-Cavalcante, A. A., de Sousa, D. P., \& de Freitas, R. M. (2015). Phytol in a pharmamedico-stance. Chemico-Biological Interactions, 240, 60-73. doi: 10.1016/j.cbi.2015.07.010

19. Islam, M. T., Streck, L., de Alencar, M. V. O. B., Cardoso Silva, S. W., da Conceição Machado, K., da Conceição Machado, K., ... de Carvalho Melo-Cavalcante, A. A. (2017). Evaluation of toxic, cytotoxic and genotoxic effects of phytol and its nanoemulsion. Chemosphere, 177, 93-101. doi: 10.1016/j.chemosphere.2017.02.145

20. Jaberian, H., Piri, K., \& Nazari, J. (2013). Phytochemical composition and in vitro antimicrobial and antioxidant activities of some medicinal plants. Food Chemistry, 136(1), 237-244. doi: 10.1016/j.foodchem.2012.07.084

21. JAKOA. (2013). Hal Ehwal Orang Asli Report of 2010.Kuala Lumpur: n. d.

22. Jalal, T. K., Ahmed, I. A., Mikail, M., Momand, L., Draman, S., Isa, M. L. M., ... Abdul Wahab, R. (2015). Evaluation of Antioxidant, Total Phenol and Flavonoid Content and Antimicrobial Activities of Artocarpus altilis (Breadfruit) of Underutilized Tropical Fruit Extracts. Applied Biochemistry and Biotechnology, 175(7), 3231-3243. doi: 10.1007/s12010-015-1499-0 
23. Jaradat, N., Hussen, F. \& Al Ali, A. (2015). Preliminary phytochemical screening, quantitative estimation of total flavonoids, total phenols and antioxidant activity of Ephedra alata Decne. Journal of Materials and Environmental Science, 6(6), 1771-1778.

24. Kumar, P. P., Kumaravel, S. \& Lalitha, C. (2010). Screening of antioxidant activity, total phenolics and GC-MS study of Vitex negundo. African Journal of Biochemistry Research, 4(7), 191-195.

25. Lappe, J., Watson, P., Travers-Gustafson, D., Recker, R., Garland, C., Gorham, E., ... McDonnell, S. L. (2017). Effect of Vitamin D and Calcium Supplementation on Cancer Incidence in Older Women. JAMA, 317(12), 1234. doi: 10.1001/jama.2017.2115

26. Lee, W. B., Kwon, H. C., Cho, O. R., Lee, K. C., Choi, S. U., Baek, N. I., \& Lee, K. R. (2002). Phytochemical constituens ofCirsium setidens Nakai and their cytotoxicity against human cancer cell lines. Archives of Pharmacal Research, 25(5), 628-635. doi: 10.1007/bf02976934

27. Mainasara, M. M., Abu Bakar, M. F., \& C Linatoc, A. (2018). Malaysian medicinal plants' potential for breast cancer therapy. Asian Journal of Pharmaceutical and Clinical Research, 11(6), 101. doi: 10.22159/ajpcr.2018.v11i6.24322

28. Mustafa, G., Arif, R., Atta, A., Sharif, S., \& Jamil, A. (2017). Bioactive Compounds from Medicinal Plants and Their Importance in Drug Discovery in Pakistan. Matrix Science Pharma, 1(1), 17-26. doi: 10.26480/msp.01.2017.17.26

29. Peh, H. Y., Tan, W. S. D., Liao, W., \& Wong, W. S. F. (2016). Vitamin E therapy beyond cancer: Tocopherol versus tocotrienol. Pharmacology \& Therapeutics, 162, 152-169. doi: 10.1016/j.pharmthera.2015.12.003

30. Ragone, D. \& Cavaletto, C. G. (2006). Sensory evaluation of fruit quality and nutritional composition of 20 breadfruit (Artocarpus, Moraceae) cultivars. Economic botany, 60(4), 335-346.

31. Ruiz-Montañez, G., Burgos-Hernández, A., Calderón-Santoyo, M., López-Saiz, C. M., VelázquezContreras, C. A., Navarro-Ocaña, A., \& Ragazzo-Sánchez, J. A. (2015). Screening antimutagenic and antiproliferative properties of extracts isolated from Jackfruit pulp (Artocarpus heterophyllus Lam). Food Chemistry, 175, 409-416. doi: 10.1016/j.foodchem.2014.11.122

32. Saad, B., Dakwar, S., Said, O., Abu-Hijleh, G., Battah, F. A., Kmeel, A., \& Aziazeh, H. (2006). Evaluation of Medicinal Plant Hepatotoxicity in Co-cultures of Hepatocytes and Monocytes. Evidence-Based Complementary and Alternative Medicine, 3(1), 93-98. doi: 10.1093/ecam/nel002

33. Sheeja, L., Lakshmi, D., Bharadwaj, S. \& Parveen, K. S. (2016). Anticancer activity of phytol purified from Gracilaria edulis against human breast cancer cell line (MCF-7). International Journal of Current Science, 19(4), 36-46.

34. Sikarwar, M. S., Hui, B. J., Subramaniam, K., Valeisamy, B. D., Yean, L. K. \& Kaveti, B. (2014). A Review on Artocarpus altilis (Parkinson) Fosberg (breadfruit). Journal of Applied Pharmaceutical Science, 4(8), 91-97.

35. Song, Y. \& Cho, S. K. (2015). . (2015). Phytol Induces Apoptosis and ROS-Mediated Protective Autophagy in Human Gastric Adenocarcinoma AGS Cells. Biochemistry \& Analytical Biochemistry, 04(04). doi: 10.4172/2161-1009.1000211

36. Sumathi, R. (2015). GC-MS Analysis of Methanol Extracts of Flowers of Allamanda neriifolia Hook. Indian Journal of Current Research, 2(1), 49-53.

37. Thakor, P., Subramanian, R. B., Thakkar, S. S., Ray, A., \& Thakkar, V. R. (2017). Phytol induces ROS mediated apoptosis by induction of caspase 9 and 3 through activation of TRAIL, FAS and TNF receptors and inhibits tumor progression factor Glucose 6 phosphate dehydrogenase in lung carcinoma cell line (A549). Biomedicine \& Pharmacotherapy, 92, 491-500. doi: 10.1016/j.biopha.2017.05.066

38. Tyagia, T. \& Argawak, M. (2017). Phytochemical screening and GC-MS analysis of bioactive constituents in the ethanolic extract of Pistia stratiotes L. and Eichhornia crassipes (Mart.) solms. Journal of Pharmacognosy and Phytochemistry, 6(1), 195-206. 
39. Van der Reest, J., \& Gottlieb, E. (2016). Anti-cancer effects of vitamin C revisited. Cell Research, 26(3), 269-270. doi: 10.1038/cr.2016.7

40. Wong, F. C., Woo, C. C., Hsu, A., \& Tan, B. K. H. (2013). The Anti-Cancer Activities of Vernonia amygdalina Extract in Human Breast Cancer Cell Lines Are Mediated through CaspaseDependent and p53-Independent Pathways. PLoS ONE, 8(10), e78021. doi:

10.1371/journal.pone.0078021 